\title{
THE BEREAN SCHOOL OF PHILADELPHIA AND THE INDUSTRIAL EFFICIENCY OF THE NEGRO
}

\author{
By Rey. Matthew Anderson, D.D., \\ Principal.
}

The industrial development of this country dates from the year eighteen hundred and sixty-two. Prior to that date the United States did but little towards the development of its great natural resources. Until then the thought which absorbed the mind of the nation was the unification of its heterogeneous peoples into one composite body politic: the great battles which were being waged over the political issues; the perplexing questions relative to the adjustment of the Indian reservations, and the anti-slavery agitations, which culminated in the emancipation of four million Negroes by Abraham Lincoln.

Prior to the year eighteen hundred and sixty-two there were not more than six schools in the entire country set apart for the manual and industrial training of American youth, and these few were of such a highly technical character and the expenses of attendance on them so great that it is quite evident that the founders had only in mind the more favored classes, boys whose fathers could afford to pay well for their education.

The poor white boy and girl, and even more the poor Negro boy and girl, were not considered as possible aspirants to these schools. Yet it is from their ranks eventually, rather than from the rich, that the country must hope to secure its defence in times of danger and peril. It is from the ranks of the poor boys on the farm, and in towns and cities, as well as from the ranks of Negro boys down in the canebrakes and rice swamps, on the cotton plantations and in the pitch tar camps of the South, that this country must hope to find the future men to fell its forests, till its soil, fire its engines, drive its locomotives, direct its industries and conduct the machinery of state. Notwithstanding this fact, the country has been slow to awake to a realization of its opportunity. It has been slow to see that by making liberal provisions for the manual and industrial training of its youth, irrespective of 
denomination or race, it would increase its own effectiveness and power.

Manual and industrial training as a system of instruction was not heartily received at first in this country, because the system was not clearly understood. Especially was this true among the colored people, by whom it was thought that the system was intended only for them, in contradistinction to the higher or mental instruction which was to be confined to the whites. They said, and rightly, that there should be no class instruction in this country. That we are but one people, and that every attempt to set up a different standard of moral, religious, political, educational or of social life, for any of the peoples which make up the body politic of this great nation, whether they be Jew or Gentile, Mongolian or Greek, Scandinavian or Italian, English or French, Scotch or Negro, should be openly resented.

But the colored people are now looking at manual training from an entirely different viewpoint. They find that it means everything to them as a people. They see that manual and industrial training is that system of instruction which will put into the Negro's hands the weapons by which he in common with his white fellowcitizens will be enabled to conquer the forces of nature and make them subservient to his will. He sees that if he would have an honorable part in the development of the great natural resources of this country, which as yet are hardly touched, he should know how to handle the secret forces of nature and make them assist him, as they are assisting his brother in white, in securing for himself and his posterity these priceless treasures.

The Negro sees more. He sees that manual training is not divorced from or a substitute for the higher training, but that it is a complement of it. That its relation to the higher or intellectual training is as intimate as body and mind, that one cannot exist without the other, any more than that mind in the flesh could exist unless it was connected with a living, organic, puissant body. Therefore, if manual training is taught aright, it should always be in connection with mental studies, not that there necessarily should be the extraction of Greek roots or the conjugation of Latin verbs, but such mental studies as will have a natural bearing upon and connection with the manual studies which are being pursued.

I have just said that manual and industrial training was not 
readily received at first, especially by the colored people, because it was not clearly understood. It remained for that noble, God-fearing man, General Samuel Chapman Armstrong, the founder and apostle of manual training in this country, and his most distinguished pupil, Dr. Booker T. Washington, to explain and popularize this system of training throughout this country. As a result, the six schools which existed in eighteen hundred and sixty-two have increased a thousandfold within the last forty years, so that there is hardly a town in the country which has not in some form its manual training and industrial school, ranging from a school consisting simply of a single class in plain sewing and dressmaking, or caning, to the great manual training and technical schools, such as are in Pittsburg and Philadelphia, founded by Messrs. Carnegie and Drexel, and the University of Pennsylvania. Consequently, the industries of this country have amazingly increased, and the United States has reached a prowess by which she excites the envy and admiration of the world.

I have been asked to speak of the industrial efficiency of the colored people and the influence of industrial education on the efficiency and character of the students of the Berean Manual Training and Industrial School. I have shown that the colored people of this country are now gladly receiving manual and industrial training because they regard it as being the strong arm which will break from them the fetters of physical tyranny and oppression.

But it would be cruel to set before a starving man a sumptuous feast and not allow him to taste any of the viands, especially if he were able to masticate and digest the food and had the perfect use of all the functions of his body. It would be infinitely more cruel if, after a man has been educated mentally and manually, and is made to see and to feel the advantages of his superior knowledge and skill, he were not permitted to make use of his abilities. The colored man has awakened to the fact that manual and industrial training will give him superior advantages, that he will be worth more to his employer, be he a mixer of mortar or a mixer of paint, a servant in his home or a clerk in his business, than he would be if he were not thus trained. But up to the present only the more humble positions, such as those in ordinary day labor and waiting have been open to the colored man. Except in a few honorable cases, the door of hope seems for the time being closed against him. 
Would that this country and the leaders of our great commercial interests could be made to see the golden opportunity that presents itself to them. Twelve millions of people are a mighty host! If this people be organized and wisely led and be suffered to enter the door of hope; if they be permitted to employ their minds and skill to the full extent of their ability, it would prove one of the mightiest forces in the development of this country. The colored man is a safe man. He is a man of peace, and he is patriotic. He is proud of his country, and he is ever ready to defend its flag, as he has proven in every war. Never once has he been recreant to his trust. The colored people are here, and here to stay. They are here as a mighty reserve force to be used in some great crisis in the nation's history. There have been times when it was thought that certain valuable products, such as coal, petroleum oil and minerals would become extinct, within a given time, if the present rate of consumption be kept up. But long years before the time expired which had been so accurately calculated, new and more productive veins of coal were discovered, purer and more abundant supplies of oil were found, richer veins of ore opened up, so that the supply is practically inexhaustible. Twenty years ago the Negro, too, was said to be dying out, that it would only be a question of time when he would become extinct. But it is found out that he must have discovered new recuperative powers, for, instead of dying out, he has added at least three millions to his number.

The Almighty Ruler of the universe has made no mistake in regard to the colored people of this country. You and I may not be able to interpret $H$ is handwriting, but we know enough, which, if we would but follow and obey, this country would soon be made to blossom as the rose. Nothing is clearer than that it is His will that these millions of American Negroes, who are thirsting for the light of knowledge and wisdom, and who are feverishly anxious to assist in making this country one of the greatest and grandest on which the sun has ever shone, should be given every encouragement in their efforts for self-government and the fullest freedom to put into operation their desire to assist in developing the great natural resources of this country.

It is because I believe in the just purposes of my people, and in the righteousness of the American people, that $I$ have been 
willing, aside from being the pastor of a church and congregation, to give a goodly portion of my time in assisting the colored people in the City of Philadelphia along economic and educational lines. This leads me to speak a word on the efficiency and character of the students of the Berean Manual Training and Industrial School.

The Berean school, or the Berean enterprise, as we are wont to call it, is unique because of its peculiar development. No thought of founding a school was entertained when a number of little tots were gathered together over twenty-five years ago and a kindergarten teacher employed to teach them. That teacher has been teaching ever since, and some of the brightest and most energetic young men and women in the city received their first instruction in this school.

Neither was there a school in mind when, on February I2th, eighteen hundred and eighty-eight, the Berean Building and Loan Association was organized. There was not the least thought that it would have such a far-reaching influence. Commencing with an enrolment of less than fifty members, we have now an enrolment of over seven hundred members. Commencing with less than fifty shares of stock, we are now carrying over twenty-seven hundred shares of stock. The assets the first year were but \$5, I I9; the assets now are over one hundred and fifty thousand dollars. When the association was organized, in I888, not a single member owned a foot of land. We now have two hundred members who own their own homes, which have an average valuation of two thousand dollars, or an aggregated valuation of four hundred thousand dollars. All of these homes were purchased through the association.

Neither was a school thought of when, in eighteen hundred and eighty-seven, some idle but promising lads were gathered and a teacher employed to instruct them in chair caning. But it was from that class of boys that the Berean Manual Training and Industrial School was evolved. On the 6th of November, eighteen hundred and ninety-nine, a number of gentlemen met in the administration room of Witherspoon Hall. Among them were Mr. John H. Converse, Judge Ashman, H. La Barre Jayne, H. L. Phillips, D.D., John B. Reeve, D.D., and Matthew Anderson. They there organized the Berean School. From twenty-five scholars, which were at first enrolled, the school has now an enrolment of over three hundred. From four teachers there are now sixteen. At first housed in temporary quarters in the basement of the Berean Presbyterian 
Church, the school now owns and occupies property valued at fifty thousand dollars. The Berean School is practically a trades school.

The thought in mind on the founding of the school was simply to assist, at night, young men and women who were at work during the day, in simple studies, such as reading, writing and arithmetic, and in two or three simple handicrafts, such as plain sewing, dressmaking and cooking. We have now classes in carpentry, upholstery, millinery, plain sewing, shirtwaist making, practical electricity, tailoring, typewriting and stenography, bookkeeping, cooking and waiting, and classes in English studies.

The school is principally held at night, from 7.45 to ro o'clock. The students come from all over the city and from out of the city as far as twenty-five miles. They come, for example, from Wilmington, Del., and from Chester, Ridley Park, Kennett Square, Bryn Mawr, Cynwyd, Wyncote, Frankford and Germantown, Penna., and from Woodbury, Camden, Merchantville, Paulsborough and Riverton, N. J. There is no school where the students show greater earnestness, nor where they make a greater sacrifice. For, when it is remembered that all the students are at work during the day and come to school two nights in the week and are in class from 8 to ro o'clock, after which they go to their homes-many of them must go from ten to twenty-five miles, and cannot reach home before half-past eleven or twelve o'clock at night-their earnest and self-sacrificing spirit can be more fully appreciated.

On the 3Ist of last December one of my students came to me and said: "Dr. Anderson, I want to fill out a blank for my wife to join the English department and to pay for her tuition. Please give me a receipt, as I wish to make her a New Year's present in the morning by handing her the receipt." That man and his wife are now coming regularly to the school twice a week at night. He is fifty and she is forty years of age. At the same time he is assisting a son through a medical college. This is only one of the many noble examples of self-sacrificing effort which might be mentioned.

The Berean School has been seriously handicapped by want of proper buildings, equipment and funds to meet its running expenses. If we had these, instead of three hundred students we would have not less than five or six hundred. Particularly during the last two years have we been very much overcrowded and, there- 
fore, very much hampered in doing our work. The desire for knowledge of the trades is growing among our people. A great awakening is taking place. So pressing became the need for space last year that one of our board members was authorized to secure a loan and to finance the erection of a new building and to leave it to me to raise the money and pay off the loan later. The general structure of that building is now finished. It is a three and a half story brick structure, very attractive in appearance and substantial in construction. The basement and the first and second floors will accommodate the principal industrial departments of the school, while the third floor is to be fitted up as a first-class gymnasium. When divided up into classrooms and provided with the latest equipment for manual training work, this will be one of the finest buildings of its kind in the city. To make the building complete will cost nearly thirty thousand dollars. Of this amount we have in hand only twelve thousand dollars. The rest must be raised by voluntary contributions from friends.

The school has purchased three dwellings immediately adjoining its present property for twenty-one thousand six hundred dollars, against which there is a mortgage of ten thousand dollars. Twenty-five thousand dollars would enable us to lift this mortgage and complete the present new building, including the furnishing of the same. I have said nothing about an endowment for the work. I am sorry that the school has no endowment. The running expenses amount to ten thousand dollars a year. Most of this money has to be raised by subscriptions.

The Berean School is the only school of the kind in the City of Philadelphia, where the colored population is estimated to be from eighty to a hundred thousand. This does not include the colored people in the suburban towns. Including the suburban towns within a radius of twenty-five miles, from which students to the Berean School are now coming, there are not less than one hundred and twenty-five thousand colored people, and they are increasing every year by the immigration of thousands from the South. They are coming from the schools and colleges of that Southland; they are coming from the rice swamps and canebrakes; they are coming from the cotton fields and pine forests; they are coming from prison cells and chain gangs; they are coming from every class of Negroes in the South, with the hope of bettering their condition; with the 
hope of commencing life anew; with the hope of escaping the law. This is a serious problem, and we should not close our eyes against it. We must bravely meet the conditions as we have met the conditions in every great emergency in the past, and convert into a blessing that which at present may seem a curse.

With the suburban towns, Philadelphia is practically the largest city in the country in point of colored population. The Negro is here and is here to stay. All the solutions to the so-called race problem which do not take this fact into consideration are foolish and will fail. Now, therefore, since he is here to stay, why not aid him in his preparation to live here in the midst of your civilization? True statesmanship will not leave him ignorant so as to become a menace to the homes and firesides of the nation. True statesmanship will not look forward to the Negro as a perpetual ward of the nation. True statesmanship will throw open the door of opportunity to him, will aid him in his rise to greatness and will be satisfied with the Negro as nothing less than a potent factor in the promotion of the highest interests of this country.

Science is constantly bringing to the attention of man forces and agents which were not thought of or were considered worthless yesterday. Our streets are lighted with a flash of lightning; we hold audible and intelligent converse with each other miles apart. The navies and merchantmen of the world on widely different seas communicate with each other and with their home governments as freely and as intelligently as men do on land; the clay under our feet, which was considered of little or no value yesterday, is yielding up treasures more valuable than gold and precious jewels to-day The thing that was despised and rejected yesterday is honored and esteemed to-day. The vessel which was cast aside as worthless yesterday is placed in our parlors and classed among our most choice bric-a-brac to-day.

Just so the Negro, who is despised, jeered at and neglected today, will be received and valued to-morrow, because it will be seen that he possesses that which the world needs and the church must have for its preservation and the consummation of the greatest good. 